\title{
Oxygen isotope composition of diatoms from sediments of Lake Kotokel (Buryatia)
}

\author{
S.S. Kostrova ${ }^{\text {a,* }}$, H. Meyer ${ }^{\text {b }}$, P.E. Tarasov ${ }^{\text {c }}$, E.V. Bezrukova ${ }^{\text {a,d }}{ }^{\text {, B. Chapligin }}{ }^{\text {, }}$, \\ A. Kossler ${ }^{\text {c }}$, L.A. Pavlova ${ }^{\text {a }}$, M.I. Kuzmin ${ }^{\text {a }}$ \\ ${ }^{a}$ Vinogradov Institute of Geochemistry, Siberian Branch of the Russian Academy of Sciences, ul. Favorskogo 1a, Irkutsk, 664033, Russia \\ ${ }^{\mathrm{b}}$ Alfred Wegener Institute of Polar and Marine Research, Bdg. A43, Telegrafenberg, Potsdam, 14473, Germany \\ ${ }^{\mathrm{c}}$ Geoforschungsinstitut, Freie Universitt Berlin, D, Malteserstrasse 74-100, 12249, Germany \\ ${ }^{\mathrm{d}}$ Institute of Archeology and Ethnography, Siberian Branch of the Russian Academy of Sciences, \\ pr. Akademika Lavrentieva 17, Novosibirsk, 630090, Russia \\ Received 6 May 2015; accepted 30 June 2015 \\ Available online xx July 2016
}

\begin{abstract}
This is a summary of new oxygen isotope data for diatoms from Lake Kotokel sediments, with implications for responses of the lake system and its environment to global change over the past $46 \mathrm{kyr}$. Fossil diatoms in all samples are free from visible contamination signatures and contain no more than $2.5 \% \mathrm{Al}_{2} \mathrm{O}_{3}$, which ensures reliable reconstructions. The $\delta^{18} \mathrm{O}$ values in diatoms vary between +23.7 and $+31.2 \%$ over the record. The results mainly represent diatom assemblages of summer blooming periods, except for the time span between 36 and $32 \mathrm{kyr}$, when the isotopic signal rather records a shift from summer to spring blooming conditions. Possible water temperature changes only partly explain the changes in the isotopic record. The observed isotopic patterns are produced mainly by isotope changes in lake water in response to variations in air temperature, hydrology, and atmospheric circulation in the region. During Marine Isotope Stage (MIS) 2 (Last Glacial maximum), high $\delta^{18} \mathrm{O}_{\text {diatom }}$ resulted from rapid evaporation and low fluvial inputs. The high $\delta^{18} \mathrm{O}$ values of about +29 to $+30 \%$ during the first half of MIS 1 (Holocene interglacial) suggest an increased share of summer rainfalls associated with southern/southeastern air transport. The $\delta^{18} \mathrm{O}$ decrease to $+24 \%$ o during the second half of MIS 1 is due to the overall hemispheric cooling and increased moisture supply to the area by the Atlantic transport. The record of Lake Kotokel sediments provides an example of complex interplay among several climatic controls of $\delta^{18} \mathrm{O}_{\text {diatom }}$ in the Late Pleistocene and the Holocene.
\end{abstract}

(C) 2016, V.S. Sobolev IGM, Siberian Branch of the RAS. Published by Elsevier B.V. All rights reserved.

Keywords: Oxygen isotope composition; lacustrine sediments; biogenic silica; climate change, hydrology; southern Siberia

\section{Introduction}

Lithology, mineralogy, and chemistry of bottom sediments have important implications for the history of lakes, sediment provenance, and responses of lake systems to global change (Sklyarov et al., 2010; Kuzmin et al., 2014). Variations in oxygen isotope composition $\left(\delta^{18} \mathrm{O}\right)$ of limnic fossils found in sediments, such as foraminifera, ostracods, or gastropods, bear imprint of their environments and can be used as a climate proxy (Faure, 1986). Isotopic records of diatom silica (frustules) have been largely studied in the past decade (Leng and Barker, 2006; Leng and Henderson, 2013; Swann and Leng, 2009). Diatom algae (Bacillariophyta) are essential constitu-

\footnotetext{
* Corresponding author.

E-mail address: kostrova@igc.irk.ru (S.S. Kostrova)
}

ents of many limnic ecosystems and, when die and sink to the bottom, become part of lake sediments representative of the respective deposition cycles. Diatom $\delta^{18} \mathrm{O}$ curves mimic variations in temperatures and oxygen isotope composition of water (Labeyrie, 1974). The values of $\delta^{18} \mathrm{O}_{\mathrm{w}}$, in turn, depend on lake hydrology and $\delta^{18} \mathrm{O}$ of regional atmospheric moisture $\left(\delta^{18} \mathrm{O}_{\mathrm{atm}}\right)$ (Leng and Barker, 2006).

Although being yet few, oxygen isotope archives available from Russia (Chapligin et al., 2012à; Jones et al., 2004; Meyer et al., 2015; Swann et al., 2010) extend the knowledge of global change, lake hydrology, and atmospheric circulation that controls moisture inputs. Specifically, $\delta^{18} \mathrm{O}_{\text {diatom data }}$ from Lake Baikal revealed general trends in the system responses to global change (Kalmychkov et al., 2007; Mackay et al., 2008, 2011, 2013; Morley et al., 2005). However, detailed climate reconstructions for the last glacial-interglacial cycle are impeded by poor isotopic age constraints (Kalmy- 
chkov et al., 2007) and low temporal resolution (Morley et al., 2005; Mackay et al., 2011) of the records. On the other hand, the isotopic signal from the enormous basin and catchment area of Lake Baikal is strongly averaged while high contamination (up to 60\%) of diatoms deposited during the Last Glacial deteriorate the data quality (Mackay et al., 2011; Morley et al., 2005).

According to interdisciplinary results (Bezrukova et al., 2010; Müller et al., 2010, 2014; Sklyarov et al., 2010), bottom sediments of small lakes furnish valuable information for reconstructions of Late Pleistocene climates and environments on different scales. Specifically, the ecosystem of Lake Kotokel located at the taiga/steppe boundary (Fig. 1) was proven (Bezrukova et al., 2008, 2010; 2011; Fedotov et al., 2012; Müller et al., 2014; Shichi et al., 2009; Tarasov et al., 2009) to be highly sensitive to heat and moisture variations. High contents of total organic carbon (TOC) and the absence of the reservoir effect allowed reliable dating of the lake sediments (Bezrukova et al., 2010). The Holocene $\delta^{18} \mathrm{O}_{\text {diatom }}$ record of the Kotokel sediments at an average resolution of $150 \mathrm{yr}$ (Kostrova et al., 2013a,b) faithfully images the general climate history of the Northern Hemisphere. In this paper we synthesize partly published (Kostrova et al., 2013a,b, 2014) and unpublished oxygen isotope data from the most representative Kotokel core KTK2 (Bezrukova et al., 2010); describe the analytical methods; and discuss the responses of the lake system to global change for the past $46 \mathrm{kyr}$ (hereafter the ages are quoted as calibrated using the CalPal curve (http://www.calpal-online.de). The results are compared with the ecological interpretation of spore-pollen and diatom data

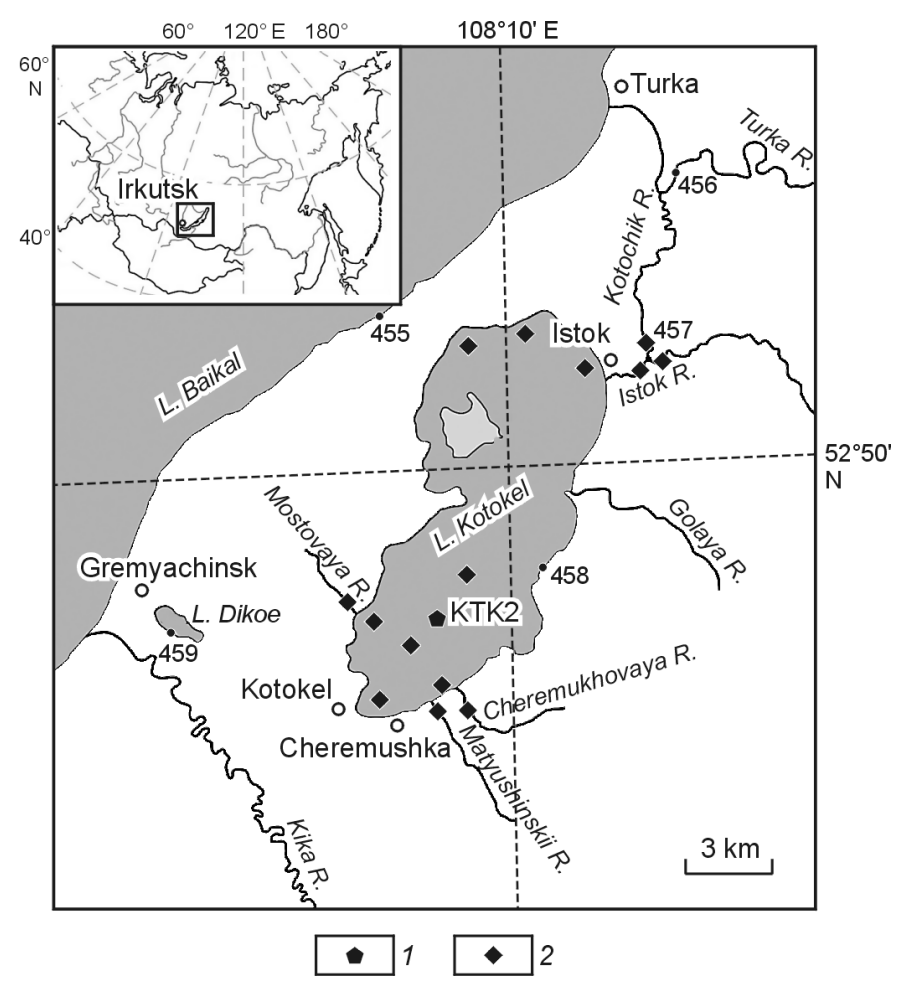

Fig. 1. Location map of Lake Kotokel. 1, KTK2 drilling site; 2, sampling sites.
(Bezrukova et al., 2008; 2010; 2011; Müller et al., 2014; Shichi et al., 2009; Tarasov et al., 2009).

\section{Study area}

Kotokel $\left(52^{\circ} 50^{\prime} \mathrm{N}, 108^{\circ} 10^{\prime} \mathrm{E}, 458 \mathrm{~m}\right.$ asl) is a relatively small (about $67 \mathrm{~km}^{2}$ ) freshwater lake, as shallow as $\sim 4 \mathrm{~m}$ on average (Zhang et al., 2013), with a catchment limited to $183 \mathrm{~km}^{2}$ (Kuzmich, 1988) and a short water renewal period of $\sim 7 \mathrm{yr}$ (Shichi et al., 2009). It extends along the Buryatian shore of Lake Baikal, between the Turka and Kika mouths (Fig. 1). Lake Kotokel is bordered by a 500-729 $\mathrm{m}$ high ridge in the north, which separates it from Baikal, by a swampy area in the south, and by the Ulan-Burgassy Range (up to $2033 \mathrm{~m}$ asl) in the east. It receives waters from several streams and creeks and discharges through the Istok River. Note that the latter can change its flow direction when the level of the Kotochik River, its tributary, rises considerably (Kostrova et al., 2012; Kuzmich, 1988). The shallow water of the lake warms up rapidly during warm seasons and lacks temperature stratification (Sheveleva and Krivenkova, 2010). The lake is covered with up to $70 \mathrm{~cm}$ thick ice from latest October to earliest May and is open from May to October, with a mean water temperature of $\sim 18{ }^{\circ} \mathrm{C}$ (Kuzmich, 1988). Its state generally reflects the continental climate of the area, with a cold winter and a moderately warm summer. The mean air temperatures are about $-20{ }^{\circ} \mathrm{C}$ in January and $+16{ }^{\circ} \mathrm{C}$ in July, while the mean annual precipitation is within $400 \mathrm{~mm}$ (Galaziy, 1993). Lake Kotokel lies at the crossways of two global air circulation systems: the Asian anticyclone and the North Atlantic transport. The western air transport predominant almost all year round fades in July and August, while the N-S transport and the polar cyclones become more active. Cyclones coming from the southeast bring warm and humid air, which causes heavy rainfalls. In autumn and winter, the area falls in the zone of high air pressure with its center over East Siberia and Mongolia, precipitation is low, and the weather is sunny but cold (Latysheva et al., 2009).

\section{Materials and methods}

Diatom frustules were extracted from a $1253 \mathrm{~cm}$ long core (KTK2) of bottom sediments sampled in the southern part of the lake at $52^{\circ} 47^{\prime} \mathrm{N} ; 108^{\circ} 07^{\prime} \mathrm{E}$ (Fig. 1), under $3.5 \mathrm{~m}$ of water, in August 2005 (Bezrukova et al., 2010). Radiocarbon dates and the respective age model, as well as lithological, sporepollen, and diatom results were detailed by Bezrukova et al. (2010). Data from the 1153-1182, 1113-1093, 1045-895 and $820-720 \mathrm{~cm}$ core intervals with extremely low diatom abundances (Fig. 2), which were deposited 42.3-40.3, 37.5-36.1, 32.8-24.7, and 22.0-17.0 kyr ago, respectively, were excluded from interpretations. Diatoms were extracted from sediments at every $5 \mathrm{~cm}$ and cleaned by means of stepwise removal of contaminants using chemical and physical separation techniques at the Institute of Geochemistry in Irkutsk (Kostrova 

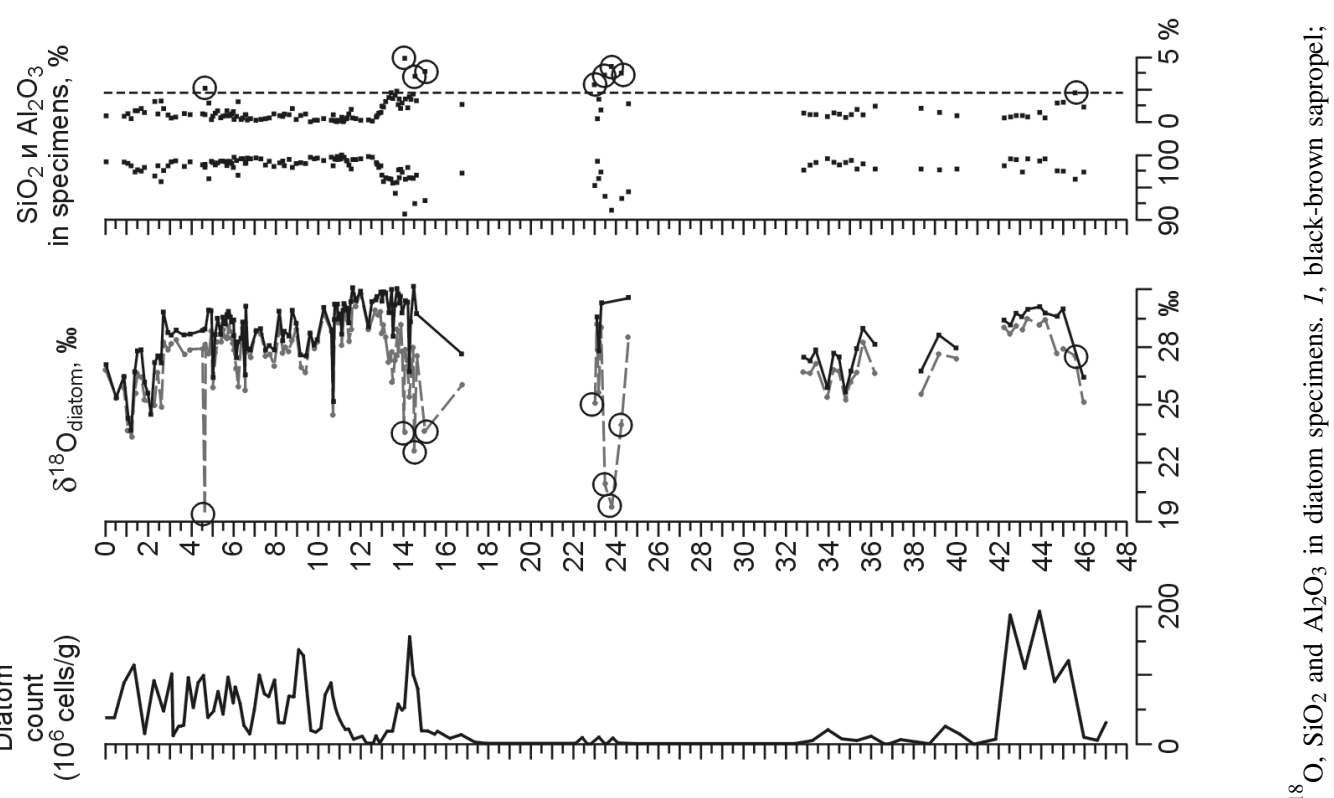

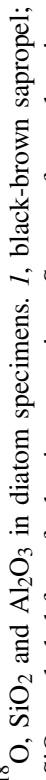
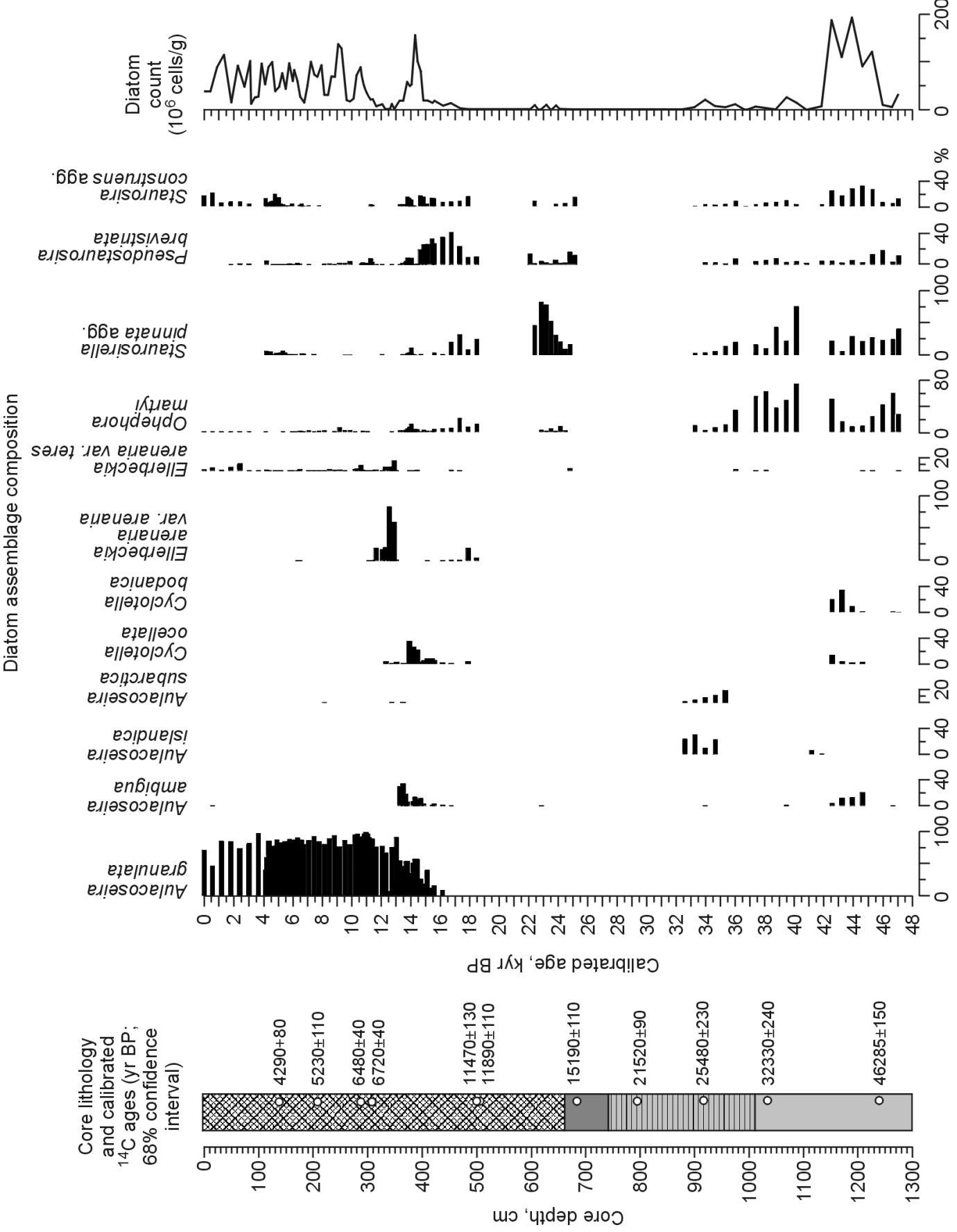

$\stackrel{\dot{a}}{\dot{a}}$ 
et al., 2013). Namely, the procedure consisted of (1) removal of organic matter by hydrogen peroxide and $\mathrm{HNO}_{3}$ and $\mathrm{HCl}$ mixture; (2) removal of clay particles by 5 ìm sieving; (3) separation of contaminants by silylation from hydrophobic diatom surfaces (Kalmychkov et al., 2005) and (4) concentration of diatoms in poly-sodium tungstate (Chapligin et al., 2012b).

The purity of diatom specimens was assessed by scanning electron microscopy (SEM) and energy dispersion spectroscopy (EDS). The quantitative analyses were performed following the standard procedures (Chapligin et al., 2012b; Pavlova et al., 2014) at the Geoforschungszentrum (Potsdam, Germany), on a ZEISS ULTRA 55 scanning electron microscope equipped with an energy dispersion system and an Ultra Dry SDD detector, as well as at the Shared-Use Analytical Center of Isotope Geochemistry of the Vinogradov Institute of Geochemistry, on a JEOL JXA8200 (Japan) electron microprobe analyzer with a JEOL EX-84055MU EDS system (Japan) with $\mathrm{Si}-\mathrm{Li}$ detector. The results are quoted as oxides, in wt.\%.

The $\delta^{\mathbf{1 8}} \mathbf{O}$ analysis of diatoms and data correction were performed at the Alfred Wegener Institute for Marine and Polar Research (AWI, Potsdam, Germany), on a PDZ Europa 2020 mass spectrometer, using the method of Chapligin et al. (2010), to the $\pm 0.25 \%$ one sigma error in $\delta^{18} \mathrm{O}$. The data quality was checked against the BFC standard (Shasta diatomite, Siskiyou County, California, with $\delta^{18} \mathrm{O}=28.80 \pm$ $0.18 \%, 1 \sigma, n=24)$.

The contamination correction was according to the mass balance equation (Chapligin et al., 2012b)

$\delta^{18} \mathrm{O}_{\text {cor. }}=\left(\delta^{18} \mathrm{O}_{\text {meas. }}-\delta^{18} \mathrm{O}_{\text {cont. }} c_{\text {cont. }} / 100\right) /\left(c_{\text {diat. }} / 100\right)$,

where $\delta^{18} \mathrm{O}_{\text {cor. }}$ are the values corrected for contamination; $\delta^{18} \mathrm{O}_{\text {meas. }}$ are the measured values; $\delta^{18} \mathrm{O}_{\text {cont. }}$ is the average per mil amount of contamination (8.1\%o for MIS 1 ; $+10.5 \%$ ofor MIS $2 ;+9.9 \%$ for MIS 3$)$; $c_{\text {cont. }}=$ $\left(c\left(\mathrm{Al}_{2} \mathrm{O}_{3}\right)_{\text {spec }}\right.$ ! $\left.c\left(\mathrm{Al}_{2} \mathrm{O}_{3}\right)_{\text {cont. }}\right) 100$ is the contaminant content; $c\left(\mathrm{Al}_{2} \mathrm{O}_{3}\right)_{\text {spec. }}$ is the content of $\mathrm{Al}_{2} \mathrm{O}_{3}$ in the specimen, \%; $c\left(\mathrm{Al}_{2} \mathrm{O}_{3}\right)_{\text {cont. }}$ is the average $\mathrm{Al}_{2} \mathrm{O}_{3}$ content in sedimentary material (13.9\% for MIS 1; $14.2 \%$ for MIS 2; $14.7 \%$ for MIS 3$) ; c_{\text {diat. }}$ is the content of diatom material as $(100 \%-$ $c_{\text {cont. }}$ ) for each specimen.

Isotope analysis of water samples. Water samples from Lake Kotokel were collected in the southern part of the lake, in the immediate vicinity of the KTK2 drilling site, as well as in its north near the Istok discharge (Fig. 1) in May and July 2011; March, September, and November 2012; July and August 2013. Sampled were also streams that are connected to the lake. Atmospheric moisture was sampled from May 2011 through October 2013 in Irkutsk, $270 \mathrm{~km}$ west of Kotokel. Isotopes in the water samples were analyzed at the AWI Isotope Laboratory on a Finnigan MAT Delta-S mass spectrometer. The $\delta \mathrm{D}$ and $\delta^{18} \mathrm{O}$ results are quoted as per mil (\%o) deviations from the V-SMOW international standard; one sigma errors in $\delta \mathrm{D}$ and $\delta^{18} \mathrm{O}$ are, respectively, \pm 0.8 and $\pm 0.1 \%$ 。 (Meyer et al., 2000).

\section{Results}

$\delta^{18} \mathrm{Ow}$ and $\delta \mathrm{Dw}$ isotope compositions of water in streams connected to Lake Kotokel and in meteoric water. The typical concentrations are from -10.8 to $-13.7 \%$ o $\delta^{18} \mathrm{O}_{\mathrm{w}}$ and -101.2 to $-114.7 \% \circ \delta \mathrm{D}_{\mathrm{w}}$ in Lake Kotokel water and $-19.7 \% 0 \delta^{18} \mathrm{O}_{\mathrm{sw}}$ and $-144.5 \% \circ \delta \mathrm{D}_{\mathrm{sw}}$ on average in stream waters flowing into the lake. The respective average values for rainfall and snow in southern Siberia are: $-11.8 \% \circ \delta^{18} \mathrm{O}_{\mathrm{r}}$; $-95.0 \delta \mathrm{D}_{\mathrm{r}}$ and $-27.7 \% \circ \delta^{18} \mathrm{O}_{\mathrm{sn}} ;-210.5 \delta \mathrm{D}_{\mathrm{sn}}$, respectively.

Purity of diatom specimens. Scanning electron microscopy of diatom specimens did not reveal visible contamination. To avoid errors from correction of $\delta^{18} \mathrm{O}$ in diatoms, the content of $\mathrm{Al}_{2} \mathrm{O}_{3}$ should be within $2.5 \%$ (Chapligin et al., 2012b). Out of 142 specimens, only nine contained 2.6-4.9\% $\mathrm{Al}_{2} \mathrm{O}_{3}$ and $90.8-95.2 \% \mathrm{SiO}_{2}$ (Fig. 2) and were excluded from further interpretation.

$\delta^{18} \mathrm{O}$ record. The curves of measured $\delta^{18} \mathrm{O}_{\text {meas. }}$ (gray dash line in Fig. 2) and corrected $\delta^{18} \mathrm{O}_{\text {cor. (black line in Fig. 2) }}$ values are similar, i.e., the correction does not change much the observed composition trends. The corrected values of $\delta^{18} \mathrm{O}$ in the Kotokel diatoms increase from 23.7 to $31.2 \%$ for the past $46 \mathrm{kyr}$ and fit the 15 to $40 \%$ range typical of limnic diatoms (Leng and Barker, 2006; Swann and Leng, 2009). The isotope record includes three distinct zones corresponding to the stages MIS 3-MIS 1 of marine oxygen stratigraphy (Fig. 3).

MIS 3 ( 46-30 kyr BP): high $\delta^{18} \mathrm{O}$ (from 29.1 to $30.1 \%$ ) in the time interval about 45.0-42.2 kyr BP, with two prominent peaks of 25.7 and $25.9 \%$ at 34.8 and $33.9 \mathrm{kyr} \mathrm{BP}$, respectively; a general trend of gradual ${ }^{18} \mathrm{O}_{\text {diatom }}$ depletion (for $\sim 4 \%$ ); the average $\delta^{18} \mathrm{O}_{\text {diatom }}$ in the zone is $28.3 \%$ o.

MIS 2 ( 30.0-11.5 kyr BP): $\delta^{18} \mathrm{O}_{\text {diatom }}$ increasing from $26.7 \%$ at $14.2 \mathrm{kyr} \mathrm{BP}$ to the $31.2 \%$ maximum recorded at $\sim 14.4 \mathrm{kyr}$; relatively stable $\delta^{18} \mathrm{O}_{\text {diatom }}$ within the $\sim 25-23 \mathrm{kyr}$ BP time span, averaging about $29.5 \%$ with a distinct local low of $27.8 \%$ at $23.2 \mathrm{kyr} \mathrm{BP}$; gradual $\sim 3.5 \%{ }^{18} \mathrm{O}_{\text {diatom }}$ enrichment between $\sim 17$ and $11.5 \mathrm{kyr} \mathrm{BP}$, while the average $\delta^{18} \mathrm{O}_{\text {diatom }}$ in the zone is $30.1 \%$.

MIS $1(\sim 11.5-0 \mathrm{kyr} \mathrm{BP}): \delta^{18} \mathrm{O}_{\text {diatom }}$ varying from a minimum of $23.7 \%$ at $\sim 1.2 \mathrm{kyr} \mathrm{BP}$ (the lowest over the diatom record) to $30.3 \%$ at $11.5 \mathrm{kyr} \mathrm{BP}$; during the 9.5-2.7 $\mathrm{kyr} \mathrm{BP}$ span, $\delta^{18} \mathrm{O}_{\text {diatom }}$ remaining within a narrow range of 27.5 to $29.9 \%$. Up the section, $\delta^{18} \mathrm{O}_{\text {diatom }}$ show a monotonic $6.6 \%$ decrease, with an average of $28.3 \%$ over the diatom zone.

\section{Discussion}

Water temperature is an important control of the $\delta^{18} \mathrm{O}_{\text {dia- }}$ tom signal (Labeyrie, 1974). The diatom assemblage of the Kotokel lake sediments (Fig. 2) develops mostly in summer at water temperatures from $\sim 7-8$ to $\sim 18-20{ }^{\circ} \mathrm{C}$, except for the spring sub-ice species Aulacoseira islandica and Aulacoseira subarctica (Barinova et al., 2006; Bezrukova et al., 2010; Fedotov et al., 2012; Kuzmich, 1988; Popovskaya et al., 2002). During the global cooling event corresponding to MIS 2, mean 
summer water temperatures were obviously colder than during the MIS 3 and MIS 1 interstadials, inferred to be about 10-12 ${ }^{\circ} \mathrm{C}$ (Bezrukova et al., 2010; Müller et al., 2014). A 6-8 ${ }^{\circ} \mathrm{C}$ water cooling leads to $1.2-1.6 \%$ o $\delta^{18} \mathrm{O}$ enrichment, as estimated with regard to the oxygen isotope fractionation between biogenic silica and water corresponding to a temperature coefficient of $-0.2 \%{ }^{\circ} \mathrm{C}$ (Swann and Leng, 2009). The $1.8 \%$ difference in average $\delta^{18} \mathrm{O}_{\text {diatom values between the }}$ warm and cold spells might be a consequence of water temperature change. However, if the $\delta^{18} \mathrm{O}$ variations were due to water temperature change alone, the reconstructed $\delta^{18} \mathrm{O}$ shifts $\sim 4 \%$ (MIS 3), 4.5\%o (MIS 2), and 6.6\% (MIS 1) would require summer water temperature warming of 20.0, 22.5 and $33.0{ }^{\circ} \mathrm{C}$, respectively, which is hardly possible. Thus, water temperature can account for only a part of the predicted $\delta^{18} \mathrm{O}$ shift in the diatom isotopic record of Lake Kotokel.

Present $\delta^{18} \mathrm{O}$ composition of water and hydrology of Lake Kotokel. Interpretation of $\delta^{18} \mathrm{O}$ signals in lake sediments requires the knowledge of present-day hydrology of the lake with implications for its possible variations in the past.

The present $\delta^{18} \mathrm{O}$ and $\delta \mathrm{D}$ compositions of water in Lake Kotokel remain relatively stable, at the average level of $12.2 \%$ o and $-107.0 \%$, respectively. These values exceed the average ones typical of atmospheric precipitation in southern Siberia $\left(\delta^{18} \mathrm{O}_{\mathrm{atm}}=-17.9 \%\right.$ and $\delta \mathrm{D}_{\mathrm{atm}} .=-139.1 \%$, according to our measurements in 2011-2013), and are much higher than $\delta^{18} \mathrm{O}$ and $\delta \mathrm{D}$ of stream waters which flow into the lake and feed mostly from seasonal ice and snow thawing. The $\delta^{18} \mathrm{O}_{\mathrm{w}}$ and $\delta \mathrm{D}_{\mathrm{w}}$ values are related linearly as $\delta \mathrm{D}_{\mathrm{w}}=5.0 \quad \delta^{18} \mathrm{O}_{\mathrm{w}}-45.9$ at a reliable approximation of $R^{2}=0.92$. The slope of this line agrees with the coefficient of the theoretical nonequilibrium evaporation relationship equal to 5 (Dansgaard, 1964), and thus is evidence of evaporation from the lake.

Isotope data indicate variations in water exchange between Lake Kotokel and Istok River (Fig. 1). For instance, in 2011 the Istok stream water had $-20.4 \%$ o $\delta^{18} \mathrm{O}$ and-151.0\% $\delta \mathrm{D}$, which is commensurate with the values $\delta^{18} \mathrm{O}=-22.0 \%$ and $\delta \mathrm{D}=-160.7 \%$ o for the Kotochik River upstream of the confluence. In 2012-2013, the composition of the Istok River with $-12.1 \%$ o $\delta^{18} \mathrm{O}$ and $-108.0 \%$ $\delta \mathrm{D}$ was similar to that of Lake Kotokel.

Thus, the shallow basin of Lake Kotokel can be either flowing or close depending on the amount of precipitation. Changes in the oxygen and deuterium isotope compositions of the lake water result from variations in atmospheric isotope ratios $\delta^{18} \mathrm{O}_{\mathrm{atm}}$. $\left(\delta \mathrm{D}_{\mathrm{atm}}\right.$.), river run-off, and evaporation.

The composition of diatom assemblages appears to cause no visible effect on the oxygen isotope signal (Chapligin et al., 2012b; Bailey et al., 2014), but the problem requires further investigation. The $\delta^{18} \mathrm{O}_{\text {diatom }}$ curve (Fig. 2) correlates with variations in percentages of diatom species. Diatoms in the lake sediments that were deposited between 46 and $36 \mathrm{kyr}$ BP were mainly benthic species (Bezrukova et al., 2010), such as Ophephora marty and Staurosirella pinnata agg. (up to 80\%; Fig. 2). In the 36-32 kyr BP interval, they gave way to spring planktonic species of Aulacoseira islandica and Aulacoseira subarctica, which led to a notable $\delta^{18} \mathrm{O}$ decrease. Staurosirella pinnata agg. again became predominant (to $82 \%$; Fig. 2) at 24.7-21.9 kyr BP while the ${ }^{18} \mathrm{O}$ enrichment of diatoms increased. The record of the $\sim 36-32 \mathrm{kyr}$ BP span reflects a shift from summer to spring blooming conditions.

Some changes to the isotope record observed between $\sim 17.0$ and $11.5 \mathrm{kyr}$ BP likewise may be associated with changed shares of planktonic and benthic species (Fig. 2) because of difference in habitat depth or blooming period (Chapligin et al., 2012b). However, the species composition hardly could cause an effect on the $\delta^{18} \mathrm{O}$ signal in that period because the diatoms discovered in sediments bloom mostly in the summer season in the absence of temperature stratification (Sheveleva and Krivenkova, 2010) and notable variations in the contents of stable isotopes in lake water. In the period 11.5-0 kyr BP, the percentage of Aulacoseira granulata reached $98 \%$ (Fig. 2), while other species were minor and caused no effect on $\delta^{18} \mathrm{O}$. Thus, the oxygen isotope record of Lake Kotokel mainly reflects the conditions of summer bloom and the assemblage composition dependence of diatom $\delta^{18} \mathrm{O}$ can be neglected. This dependence was possibly significant in the $~ 36-32$ kyr BP interval only.

The above factors control the $\delta^{18} \mathrm{O}$ signals in different ways, and the interpretation of diatom oxygen isotope records should take into account their interplay besides the individual effects.

$\delta^{\mathbf{1 8}} \mathbf{O}_{\text {diatom }}$ record and lake environment. The $\delta^{18} \mathrm{O}_{\text {diatom }}$ values from Lake Kotokel (Fig. 3) vary notably and in response to climate instability in southern East Siberia for the past 46 kyr.

Tundra-steppe landscapes in the lake catchment inferred for the $46-42$ kyr BP time span (Fig. 3), along with predominance of benthic species in lake sediments (Fig. 2), indicate cold and dry conditions, rapid erosion, and a short ice-free period (Bezrukova et al., 2010). The climate became slightly warmer at $~ 45-42 \mathrm{kyr} \mathrm{BP}$, when forests expanded (Fig. 3) and planktonic diatoms appeared (Fig. 2). High $\delta^{18} \mathrm{O}$ of diatoms (29.8\%o) between 46 and $42 \mathrm{kyr}$ BP evidence that Lake Kotokel was a close system subject to evaporation and fed mainly from summer rainfall. Judging by the isotope data, the lake level at $\sim 46-42 \mathrm{kyr}$ BP was lower than the present one. The low lake stand is confirmed by relatively high percentages of water-side grass pollen delineating a past shoreline position closer to the drilling site, at a reduced lake area (Bezrukova et al., 2010).

Cooling between $\sim 2$ and 35 kyr BP in southern Siberia partly coincided with the Northern Atlantic Heinrich 4 (H4) event (Heinrich, 1988; Svensson et al., 2008). During that event, the area of boreal forests in the Lake Kotokel basin reduced notably (Fig. 3) while the diatom abundances (Fig. 2) became much lower (Bezrukova et al., 2010). The oxygen isotope record (Fig. 3) shows an average $\delta^{18} \mathrm{O}$ decrease of $\sim 2 \%$, but the general level of $\delta^{18} \mathrm{O}_{\text {diatom values during the }}$ cold and dry H4 event was lower than during the $\sim 24.7-23$ kyr BP glacial maximum: about $27.8 \%$ against $29.5 \%$ o (Fig. 3). Most likely, the climate at $\sim 40-38 \mathrm{kyr}$ BP was not as cold and dry as at $\sim 24.7-23 \mathrm{kyr} \mathrm{BP}$, and/or evaporation from the lake surface was less intense. Wet winters at $\sim 43-34$ 


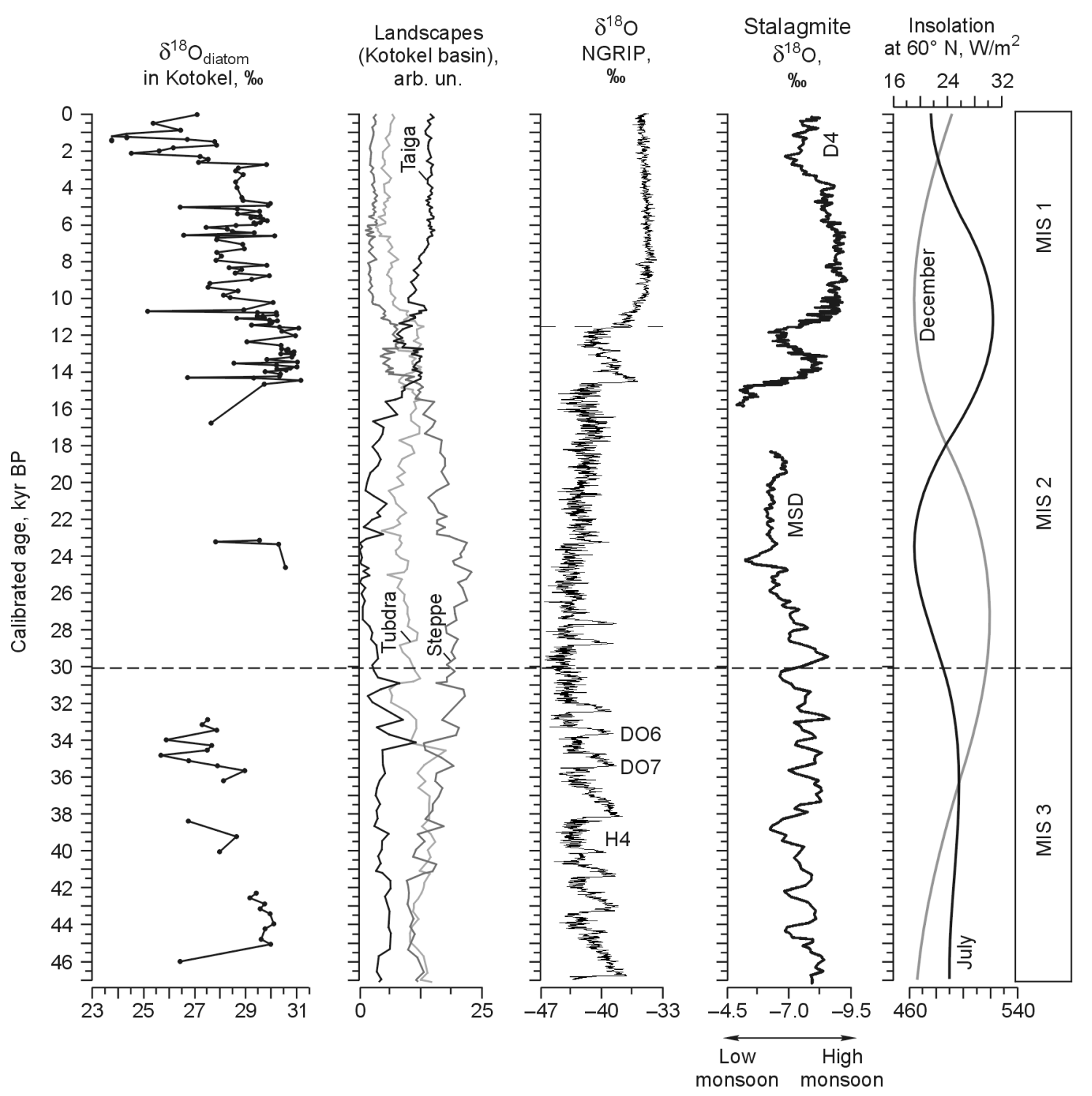

Fig. 3. $\delta^{18} \mathrm{O}_{\text {diatom }}$ in Lake Kotokel sediments and landscapes in the lake basin reconstructed from pollen data (Bezrukova et al., 2010), with $\delta^{18} \mathrm{O}$ NGRIP variations as a proxy of air temperature in Northern Hemisphere (Svensson et al., 2008); $\delta^{18} \mathrm{O}$ variations in D4 and MSD stalagmites from Dongge and Hulu caves (China) as a proxy of Pacific summer monsoon precipitation (Yuan et al., 2004); curves of summer (below dash line) and winter (above dash line) insolation (Berger and Loutre, 1991). DO6, DO7 are Dansgaard-Oeschger warm excursions (Svensson et al., 2008), H4 is the North Atlantic Heinrich 4 event (Heinrich, 1988). MIS 1, MIS 2, MIS 3 are time equivalents of stages 1,2,3 of marine oxygen stratigraphy.

kyr BP were inferred for Central Mongolia (Rother et al., 2014), while the Kotokel deposits from that interval bear more abundant Alnus fruticosa growing in wet but not swampy areas with thick seasonal snow compared to the values for the 24.7-23.0 kyr BP interval (Bezrukova et al., 2010).

In the $\sim 36-32 \mathrm{kyr} \mathrm{BP}$ interval, $\delta^{18} \mathrm{O}_{\text {diatom }}$ in the Kotokel archive (Fig. 3) decreases gradually and matches the cooling trend evident in the paleoclimate records of Mongolia (Rother et al., 2014), North China (Wen et al., 2008), and Yakutia (Müller et al., 2010). The Kotokel $\delta^{18} \mathrm{O}$ signal agrees with the general temperature trend reconstructed from Greenland ice cores: the maximums $29.0 \%$ at $\sim 35.8 \mathrm{kyr} \mathrm{BP}$ and $27.9 \%$ at $\sim 33.4$ kyr BP correlate with the time of the Dansgaard-Oesch- ger events (DO7 and DO6 in Fig. 3) of the global stratigraphy (Svensson et al., 2008).

Generally, gradual ${ }^{18} \mathrm{O}$ depletion at $\sim 46-32$ kyr BP (Fig. 3) inversely correlates with the winter insolation trend. The lack of visible response to summer insolation changes (Fig. 3) (Berger and Loutre, 1991) indicates low sensitivity of the oxygen isotope record to this factor during MIS 3. Decrease of $\delta^{18} \mathrm{O}$ values in the Kotokel diatom record (Fig. 3) corresponds to general air cooling in the Northern Hemisphere (Svensson et al., 2008).

Air cooling leads to atmospheric $\delta^{18} \mathrm{O}_{\text {atm. }}$. decrease and the ensuing decrease in the $\delta^{18} \mathrm{O}$ values of water and diatoms (Dansgaard, 1964). However, high average $\delta^{18} \mathrm{O}_{\text {diatom }}$ (30.1\%o) during MIS 2 disagrees with the temperature trend 
in mid-latitude Northern Hemisphere. The high diatom $\delta^{18} \mathrm{O}$ values at 25.0-11.5 kyr BP, when the climate was drier and colder than at present (Bezrukova et al., 2010; Goldberg et al., 2010; Müller et al., 2014; Tarasov et al., 2009), were due to water temperature cooling (see above), as well as to low moisture. Rapid evaporation at mainly clear weather and climate drying associated with cooling in central Asia (Karabanov et al., 2004; Goldberg et al., 2010) led to lake level fall in Mongolia and China (Kramer et al., 2010). The lower lake level in Kotokel during MIS 2 was confirmed by echo sounding data (Zhang et al., 2013). During cold stages, when the Asian anticyclone persisted over the greatest part of the year, winters in southern Siberia were long and dry while the summer cyclone activity was low (Morley et al., 2005), which reduced the water input into Lake Kotokel and oxygen isotope enrichment of lake water.

On transition from MIS 2 to MIS 1 about 11.7-11.6 kyr $\mathrm{BP}, \delta^{18} \mathrm{O}_{\text {diatom }}$ in the Lake Kotokel record decrease gradually (Fig. 3) as a result of permafrost degradation in the catchment and greater meltwater inputs into the lake (Bezrukova et al., 2010, 2011). The diatom abundances in lake sediments increase about 11.5-10.0 kyr BP, with predominant planktonic species and almost disappearing benthic species (Fig. 2), this being evidence of greater nutrient inputs and higher lake stand (Bezrukova et al., 2010). The high $\delta^{18} \mathrm{O}$ in diatoms about 29-30\%o in the first half of MIS 1 corresponds to high summer insolation (Fig. 3) due to mostly Pacific air transport (Kostrova et al., 2013a,b). Spore-pollen data indicate only minor effect of the North Atlantic air transport on the climate of Kazakhstan and southern Siberia at 11-9 kyr BP (Rudaya et al., 2009; Bezrukova et al., 2010). As the monsoon circulation in eastern Eurasia (Yuan et al., 2004) increased during that period (Fig. 3), the share of summer rainfall due to southern/southeastern air transport was greater than it is now (Bezrukova et al., 2010).

The western air transport increased and the summer monsoon abated in the second half of MIS 1 in Central Asia (Fig. 3), which changed the water budget of the area. As more moisture came to southern Siberia with Atlantic air flows (Bezrukova et al., 2010) and the climate became colder at lower insolation (Berger and Loutre, 1991), $\delta^{18} \mathrm{O}_{\text {diatom de- }}$ creased to $24 \%$ (Fig. 3).

\section{Conclusions}

The oxygen isotope archive of Lake Kotokel for the past 46 kyr records a highly variable climate in southern Siberia controlled by global cooling and warming trends in the Northern Hemisphere and regional changes of air circulation responsible for the amount and distribution of moisture in the area. The values of $\delta^{18} \mathrm{O}_{\text {diatom }}$ decreased in the period $42-35$ kyr BP because of mainly snow feeding of the lake but increased because of greater summer rainfalls in the 46-42 and 11.5-10.0 kyr BP intervals. Evaporation, lower river run-off, and water cooling were responsible for high diatom $\delta^{18} \mathrm{O}$ at $25.0-11.5 \mathrm{kyr} \mathrm{BP}$. The high share of atmospheric precipitation associated with southern and southeastern air transport in the regional water budget at $\sim 11-9 \mathrm{kyr} B \mathrm{~B}$, as well as subsequent increase of western transport since $\sim 6 \mathrm{kyr}$ $\mathrm{BP}$, explain well the oxygen isotope trend of MIS 1. The values of $\delta^{18} \mathrm{O}$ decreased gradually at $36-32 \mathrm{kyr} \mathrm{BP}$, as the summer benthic communities changed to the spring planktonic ones.

Thus, the Lake Kotokel record correlated with the published paleoclimate reconstructions reflects global change and accounts for the specific regional climate and landscape patterns of southern Siberia. The reported results provide the first evidence of the regional response to the global circulation change in the early Holocene: increase of the Asian summer monsoon and decrease of the North Atlantic transport. This study highlights the importance of oxygen isotope analysis of fossil diatoms in lake sediments for paleoclimate reconstructions for southern Siberia and Eurasia as a whole.

The study was supported by grants 14-50-00036 from the Russian Science Foundation; 15-05-01644 from the Russian Foundation of Basic Research; Me-3266-3-1, Me-3266-5-1 and TA-540-5-1 from the German Science Foundation (DFG); and A-13-00095 from the German Academic Exchange Service (DAAD). It was carried out as part of integration program "Basic Research and Breakthrough Technologies for Advanced Development of the Baikal Region and Its Interregional Relations".

\section{References}

Bailey, H.L., Henderson, A.C.G., Sloane, H.J., Snelling, A., Leng, M.J., Kaufman, D.S., 2014. The effect of species on lacustrine $\delta^{18} \mathrm{O}_{\text {diatom }}$ and its implications for palaeoenvironmental reconstructions. J. Quatern. Sci. 29 (4), 393-400.

Barinova, S.S., Medvedeva, L.A., Anisimova, O.V., 2006. Biodiversity of Diatoms as a Climate Proxy [in Russian]. Pilies Studio, Tel-Aviv, 498 pp.

Berger, A., Loutre, M.F., 1991. Insolation values for the climate of the last 10 million years. Quatern. Sci. Rev. 10, 297-317.

Bezrukova, E.V., Krivonogov, S.K., Takahara, K.H., Letunova, P.P., Shichi, K., Abzaeva, A.A., Kulagina, N.V., Zabelina, Yu.S., 2008. Lake Kotokel as a stratotype for the Late Glacial and Holocene in southeastern East Siberia. Dokl. Earth. Sci. 420 (2), 658-663.

Bezrukova, E.V., Tarasov, P.E., Solovieva, N., Krivonogov, S.K., Riedel, F., 2010. Last glacial-interglacial vegetation and environmental dynamics in southern Siberia: Chronology, forcing and feedbacks. Palaeogeogr., Palaeoclimatol., Palaeoecol. 296, 185-198.

Bezrukova, E.V., Tarasov, P.E., Kulagina, N.V., Abzaeva, A.A., Letunova, P.P., Kostrova, S.S., 2011. Palynological study of Lake Kotokel' bottom sediments (Lake Baikal region). Russian Geology and Geophysics (Geologiya i Geofizika) 52 (4), 458-467 (586-595).

Chapligin, B., Meyer, H., Friedrichsen, H., Marent, A., Sohns, E., Hubberten, H.-W., 2010. A high-performance, safer and semi-automated approach for the $\delta^{18} \mathrm{O}$ analysis of diatom silica and new methods for removing exchangeable oxygen. Rapid Communications in Mass Spectrometry 24, 2655-2664.

Chapligin, B., Meyer, H., Swann, G.E.A., Meyer-Jacob, C., Hubberten, H.-W., 2012a. A 250 ka oxygen isotope record from diatoms at Lake El'gygytgyn, far east Russian Arctic. Clim. Past. 8, 1621-1636.

Chapligin, B., Meyer, H., Bryan, A., Snyder, J., Kemnitz, H., 2012b. Assessment of purification and contamination correction methods for analyzing the oxygen isotope composition from biogenic silica. Chem. Geol. 300-301, 185-199.

Dansgaard, W., 1964. Stable isotopes in precipitation. Tellus 16, 436-468. 
Faure, G., 1986. Principles of Isotope Geology, second ed. Wiley \& Sons, New York.

Fedotov, A.P., Vorobyeva, S.S., Vershinin, K.E., Nurgaliev, D.K., Enushchenko, I.V., Krapivina, S.M., Tarakanova, K.V., Ziborova, G.A., Yassonov, P.G., Borissov, A.S., 2012. Climate changes in East Siberia (Russia) in the Holocene based on diatom, chironomid and pollen records from the sediments of Lake Kotokel. J. Paleolimnol. 47, 617-630.

Galazii, G.I. (Ed.), 1993. Baikal. An Atlas [in Russian]. Federal Surveys of Geodesy and Cartography of Russia, Moscow, 160 pp.

Goldberg, E.L., Chebykin, E.P., Zhuchenko, N.A., Vorobyeva, S.S., Stepanova, O.G., Khlystov, O.M., Ivanov, E.V., Weinberg, E., Gvozdkov, A.N., 2010. Uranium isotopes as proxies of the environmental history of the Lake Baikal watershed (East Siberia) during the past 150 ka. Palaeogeogr., Palaeoclimatol., Palaeoecol. 294, 16-29.

Heinrich, H., 1988. Origin and consequences of cyclic ice rafting in the northeast Atlantic Ocean during the past 130,000 years. Quatern. Res. 29, $142-152$.

Jones, V.J., Leng, M.J., Solovieva, N., Sloane, H.J., Tarasov, P.E., 2004. Holocene climate of the Kola Peninsula; evidence from the oxygen isotope record of diatom silica. Quatern. Sci. Rev. 23, 833-839.

Kalmychkov, G.V., Kostrova, S.S., Geletii, V.F., Tkachenko, L.L., Rakhlin, V.I., 2005. Isolation of diatoms from lake sediments for $\delta^{18} \mathrm{O}$ determination and paleoclimate reconstructions. Geokhimia, No. 12, 1358-1360.

Kalmychkov, G.V., Kuzmin, M.I., Pokrovsky, B.G., Kostrova, S.S., 2007. Oxygen isotopic composition in diatom algae frustules from Lake Baikal sediments: annual mean temperature variations during the last $40 \mathrm{Ka}$. Dokl. Earth Sci. 412 (5), 206-209.

Karabanov, E., Williams, D., Kuzmin, M., Sideleva, V., Khursevich, G., Prokopenko, A., Solotchina, E., Tkachenko, L., Fedenya, S., Kerber, E., 2004. Ecological collapse of Lake Baikal and Lake Hovsgol ecosystems during the Last Glacial and consequences for aquatic species diversity. Palaeogeogr., Palaeoclimatol., Palaeoecol. 209, 227-243.

Kostrova, S.S., Meyer, K.H., Chapligin, B., Bezrukova, E.V., 2012. Isotope data from Lake Kotokel. Vestnik IrGTU, No. 9, 62-68.

Kostrova, S.S., Meyer, KH., Chapligin, B., Bezrukova, E.V., Tarasov, P.E., Kuzmin, M.I., 2013a. Reconstruction of the Holocene climate of Transbaikalia: evidence from the oxygen isotope analysis of fossil diatoms from Kotokel Lake. Dokl. Earth Sci. 451 (1), 732-736.

Kostrova, S.S., Meyer, H., Chapligin, B., Kossler, A., Bezrukova, E.V., Tarasov, P.E., 2013b. Holocene oxygen isotope record of diatoms from Lake Kotokel (southern Siberia, Russia) and its palaeoclimatic implications. Quatern. Int. 290-291, 21-34.

Kostrova, S.S., Meyer, H., Chapligin, B., Tarasov, P.E., Bezrukova, E.V., 2014. The last glacial maximum and late glacial environmental and climate dynamics in the Baikal region inferred from an oxygen isotope record of lacustrine diatom silica. Quatern. Int. 348, 25-36.

Kramer, A., Herzschuh, U., Mischke, S., Zhang, C., 2010. Late glacial vegetation and climate oscillations on the southeastern Tibetan Plateau inferred from the Lake Naleng pollen profile. Quatern. Res. 73, 324-335.

Kuzmich, V.N. (Ed.), 1988. Bioproductivity of Eutrophic Lakes Irkan and Kotokel in the Lake Baikal Basin [in Russian]. Promrybvod, Leningrad.

Kuzmin, M.I., Bychinsky, V.A., Kerber, E.V., Oshchepkova, A.V., Goreglyad, A.V., Ivanov, E.V., 2014. Chemical composition of sediments in Baikal deep-water boreholes as a basis for reconstructions of climatic and environmental changes. Russian Geology and Geophysics (Geologiya i Geofizika) 55 (1), 1-17 (3-22).

Labeyrie, L.D., 1974. New approach to surface seawater palaeotemperatures using ${ }^{18} \mathrm{O} /{ }^{16} \mathrm{O}$ ratios in silica of diatom frustules. Nature $248,40-42$.

Latysheva, I.V., Sinyukovich, V.N., Chumakova, E.V., 2009. Current hydrometeorology of the southern shore of Lake Baikal. Izv. IGU, Ser. Geosciences 2 (2), 117-133.

Leng, M.J., Barker, P.A., 2006. A review of the oxygen isotope composition of lacustrine diatom silica for palaeoclimate reconstruction. Earth-Sci. Rev. 75, 5-27.

Leng, M.J., Henderson, A.C.G., 2013. Recent advances in isotopes as palaeolimnological proxies. J. Paleolimnol. 49, 481-496.

Mackay A.W., Karabanov E., Leng M.J., Sloane H.J., Morley D.W., Panizzo V.N., Khursevich G., Williams, D., 2008. Reconstructing hydro- logical variability in Lake Baikal during MIS 11: an application of oxygen isotope analysis of diatom silica. J. Quatern. Sci. 23, 365-374.

Mackay, A.W., Swann, G.E.A., Brewer, T.S., Leng, M.J., Morley, D.W., Piotrowska, N., Rioual, P., White, D., 2011. A reassessment of late glacial-Holocene diatom oxygen isotope record from Lake Baikal using a geochemical mass-balance approach. J. Quatern. Sci. 26 (6), 627-634.

Mackay A.W., Swann G.E.A., Fagel N., Fietz S., Leng M.J., Morley D., Rioual P., Tarasov P. Hydrological instability during the Last Interglacial in central Asia: a new diatom oxygen isotope record from Lake Baikal. Quatern. Sci. Rev., 2013, 66, p. 45-54.

Meyer, H., Schonicke, L., Wand, U., Hubberten, H.-W., Friedrichsen, H., 2000. Isotope studies of hydrogen and oxygen in ground ice-experiences with the equilibration technique. Isotopes in Environmental and Health Studies 36, 133-149.

Meyer, H., Chapligin, B., Hoff, U., Nazarova, L., Diekmann, B., 2015. Oxygen isotope composition of diatoms as Late Holocene climate proxy at Two-Yurts Lake, Central Kamchatka, Russia. Glob. Planet. Change 134, 118-128.

Morley, D.W., Leng, M.J., Mackay, A.W., Sloane, H.J., 2005. Late glacial and Holocene environmental change in the Lake Baikal region documented by oxygen isotopes from diatom silica. Glob. Planet. Change 46, 221-233.

Müller, S., Tarasov, P.E., Andreev, A.A., Tütken, T., Gartz, S., Diekmann, B., 2010. Late Quaternary vegetation and environments in the Verkhoyansk Mountains region (NE Asia) reconstructed from a 50-kyr fossil pollen record from Lake Billyakh. Quatern. Sci. Rev. 29, 2071-2086.

Müller, S., Tarasov, P.E., Hoelzmann, P., Bezrukova, E.V., Kossler, A., Krivonogov, S.K., 2014. Stable vegetation and environmental conditions during the Last Glacial Maximum: New results from Lake Kotokel (Lake Baikal region, southern Siberia, Russia). Quatern. Int. 348, 14-24.

Pavlova, L.A., Tkachenko, L.L., Goreglyad, A.V., Kuzmin, M.I., 2014. EMPA measurements of elements (inorganic components) in diatoms. Metody i Ob'ekty Khimicheskogo Analiza 9 (2), 65-72.

Popovskaya, G.I., Genkal, S.I., Likhoshway, E.N., 2002. Planktonic Diatoms in Lake Baikal. Identification Guide [in Russian]. Nauka, Novosibirsk.

Rother, H., Lehmkuhl, F., Fink, D., Nottebaum, V., 2014. Surface exposure dating reveals MIS-3 glacial maximum in the Khangai Mountains of Mongolia. Quatern. Res. 82, 297-308.

Rudaya, N., Tarasov, P., Dorofeyuk, N., Solovieva, N., Kalugin, I., Andreev, A., Daryin, A., Diekmann, B., Riedel, F., Tserendash, N., Wagner, M., 2009. Holocene environments and climate in the Mongolian Altai reconstructed from the Hoton-Nur pollen and diatom records: a step towards better understanding climate dynamics in Central Asia. Quatern. Sci. Rev. 28, 540-554.

Sheveleva, N.G., Krivenkova, I.F., 2010. Zooplankton in Lake Kotokel: Composition and structure. Zhurnal Sibirskogo Federalnogo Universiteta. Ser. Biol. 3 (3), 278-291.

Shichi, K., Takahara, H., Krivonogov, S.K., Bezrukova, E.V., Kashiwaya, K., Takehara, A., Nakamura, T., 2009. Late Pleistocene and Holocene vegetation and climate records from Lake Kotokel, central Baikal region. Quatern. Int. 205, 98-110.

Sklyarov, E.V., Solotchina, E.P., Vologina, E.G., Ignatova, N.V., Izokh, O.P., Kulagina, N.V., Sklyarova, O.A., Solotchin, P.A., Stolpovskaya, V.N., Ukhova, N.N., Fedorovsky, V.S., Khlystov, O.M., 2010. Detailed Holocene climate record from the carbonate section of saline Lake TsaganTyrm (West Baikal area). Russian Geology and Geophysics (Geologiya i Geofizika) 51 (3), 237-258 (303-328).

Svensson, A., Andersen, K.K., Bigler, M., Clausen, H.B., Dahl-Jensen, D., Davies, S.M., Johnsen, S.J., Muscheler, R., Parrenin, F., Rasmussen, S.O., Röthlisberger, R., Seierstad, I., Steffensen, J.P., Vinther, B.M., 2008. A 60000 year Greenland stratigraphic ice core chronology. Clim. Past 4, 47-57.

Swann, G.E.A., Leng, M.J., 2009. A review of diatom $\delta^{18} \mathrm{O}$ in palaeoceanography. Quatern. Sci. Rev. 28, 384-398.

Swann, G.E.A., Leng, M.J., Juschus, O., Melles, M., Brigham-Grette, J., Sloane, H.J., 2010. A combined oxygen and silicon diatom isotope record of Late Quaternary change in Lake El'gygytgyn, North East Siberia. Quatern. Sci. Rev. 29, 774-786.

Tarasov, P.E., Bezrukova, E.V., Krivonogov, S.K., 2009. Late Glacial and Holocene changes in vegetation cover and climate in southern Siberia 
derived from a $15 \mathrm{kyr}$ long pollen record from Lake Kotokel. Clim. Past. 5, 285-295.

Wen, X., Li, B., Zheng, Y., Zhang, D.D., Ye J., 2008. Climate variability in the Salawusu River valley of the Ordos Plateau (Inner Mongolia, China) during Marine Isotope Stage 3. J. Quatern. Sci. 24, 61-74.

Yuan, D.X., Cheng, H., Edwards, R.L., Dykoski, C.A., Kelly, M.J., Zhang, M.L., Qing, J.M., Lin, Y.S., Wang, Y.J., Wu, J.Y., Dorale, J.A.,
An, Z.S., Cai, Y.J., 2004. Timing, duration, and transitions of the Last Interglacial Asian monsoon. Science 304, 575-578.

Zhang, Y., Wünnemann, B., Bezrukova, E.V., Ivanov, E.V., Shchetnikov, A.A., Nourgaliev, D., Levina, O.V., 2013. Basin morphology and seismic stratigraphy of Lake Kotokel, Baikal region, Russia. Quatern. Int. 290-291, 57-67. 